\title{
The Existence of International Criminal Justice and Liability
}

\author{
Adedara $\mathrm{V}^{1}$ and Dada $\mathrm{F}^{{ }^{2}}$ \\ ${ }^{1}$ LLB, (Ife) LLM (UK), BL, PhD Student of the College of Law Igbinedion University, Okada, Solicitor England and \\ Wales, Nigeria \\ ${ }^{2}$ LLB (Hons) (Ife), LL.M (Chicago), SJD (Chicago), BL is a Senior Lecturer at the Department of Jurisprudence \& \\ International Law, Faculty of Law, Ekiti State University, Ado-Ekiti, Nigeria
}

${ }^{*}$ Corresponding author: Dada F, LLB (Hons) (Ife), LL.M (Chicago), SJD (Chicago), BL is a Senior Lecturer at the Department of Jurisprudence \& International Law, Faculty of Law, Ekiti State University, Ado-Ekiti, Nigeria, E-mail address: folukedada@gmail.com

Citation: Adedara V and Dada F (2017) The Existence of International Criminal Justice and Liability. J Forensic Sci Criminol 5(1): 104. doi: 10.15744/2348-9804.5.104

Received Date: November 21, 2016 Accepted Date: February 27, 2017 Published Date: February 28, 2017

\begin{abstract}
International Criminal Justice is seen with the bi-focal lens of liability under municipal laws, enforced by the local courts and international laws enforced by international tribunals. Another limb to this is the application of Customary International Laws to crimes within national jurisdictions as certain crimes are seen as universal deeming such submergible under municipal laws. Implementation of treaties become relevant in this regard due to the important roles of consenting nations in abiding by the principles of law designed to tackle crimes internationally and the exigent need to keep the peace within the local jurisdictions. It is rather tempting to argue that there is no such thing as 'international criminal justice', due to the several exclusion canvassed in this paper especially the weakness of international criminal law in piracy, torture, drug trafficking, money laundering, cyber-crime, bribery and corruption; but contrary to this view, these exclusions leave the accepted four categories of 'crime accepted in the latter half of twentieth century as the core international crimes recognized under international law. The threefold objectives of International Criminal Law will be discussed in this paper while elaborating on the four core areas of international crime. This paper argues that International Criminal Justice system hinges it reliability and sustenance on municipal laws providing expressly for such in the statutes that set up the International Criminal Court. Liability is therefore dependent on the general definition of the crime and the general principles of responsibility under the law.
\end{abstract}

Keywords: Criminal Justice; Liability; Human rights; Genocide; local courts and international laws

\section{Introduction}

The International Criminal Court (ICC) is the first permanent, independent court capable of investigating and bringing to justice individuals who commits the most serious violations of international humanitarian law, namely war crimes, crimes against humanity, genocide and, once defined, aggression. The Court is seated in The Hague, Netherlands and was established in accordance with the Rome Statute, the ICC's founding treaty, on 1 July 2002. To date, the ICC treaty has been ratified by 100 States, with representation from every region of the world more than 250 conflicts have erupted around the world since 50 years ago; more than 86 million civilians, mostly women and children, died in these conflicts; and over 170 million people were stripped of their rights, property and dignity. Most of these victims have been simply forgotten and few perpetrators have been brought to justice ${ }^{3}$.

The United Nations General Assembly first recognized the need for a permanent mechanism to prosecute mass murderers and war criminals in 1948, following the Nuremberg and Tokyo trials after World War II. Since that time, numerous laws, treaties, conventions and protocols have defined and forbidden everything from war crimes to poison gas and chemical weapons, yet no system was proposed to enforce these norms by holding individuals criminally responsible for the most serious violations of international law until the adoption of the Rome Statute of the International Criminal Court in 1998 [1]. In addition to bringing justice to victims of such atrocities, the ICC hopes to serve as a deterrent to the future Hitlers, Milosevics and Pol Pots, bringing an end to the culture of impunity.

The Court has jurisdiction over the most serious crimes committed by individuals: genocide, crimes against humanity, war crimes and once defined, aggression. The first three crimes are carefully defined in the Statute to avoid ambiguity or vagueness. The

${ }^{1 *}$ Vincent .O. Adedara, LLB,(ife) LLM (UK), BL, PhD Student of the College of Law Igbinedion University, Okada, Solicitor England and Wales

${ }^{2}$ Dr. Foluke Dada LL.B (Hons) (Ife), LL.M (Chicago), SJD (Chicago), BL is an Assistant Professor of Law at the American University of Nigeria, Yola. Adamawa State and a Senior Lecturer of Law at the Ekiti State University Ado Ekiti, Nigeria

${ }^{3}$ Coalition of International Criminal Court, http://www.iccnow.org.cicc@iccnow.org 
crime of aggression will be dealt with by the Court when the Assembly of States Parties has agreed on the definition, elements and conditions under which the Court will exercise jurisdiction; this cannot happen until the Review Conference which will be held in 2009 , seven years after entry into force of the Rome Statute. It is important to note that the Rome Statute does not identify any new categories of crimes, but rather reflects existing conventional and customary international law. Genocide covers those specifically listed prohibited acts (e.g. killing, causing serious harm) committed with intent to destroy, in whole or in part, a national, ethnic, racial or religious group. Crimes against humanity cover those specifically listed prohibited acts when committed as part of a widespread or systematic attack directed against any civilian population. Such acts include murder, extermination, rape, sexual slavery, the enforced disappearance of persons and the crime of apartheid, among others. Genocide and crimes against humanity are punishable irrespective of whether they are committed in time of "peace" or of war".

War crimes cover grave breaches of the Geneva Conventions of 1949 and other serious violations of the laws of war, committed on a large scale in international as well as internal armed conflicts [2]. The inclusion of internal conflicts is consistent with customary international law and reflects the reality that in the past 50 years, the most serious violations of human rights have occurred not in international conflicts but within States.

The definitions of the crimes in the Statute are the product of years of hard work involving many delegations and their experts. The judges of the Court are required to strictly construe the definitions and are not to extend them by analogy. The aim is to establish objective international standards, leaving no room for arbitrary decisions. In cases of ambiguity, the definitions are to be interpreted in favour of the suspect or accused. Since the entry into force of the Rome Statute on 1 July 2002 , the ICC has jurisdiction over crimes committed by nationals of States that have ratified the ICC statute, as well as over crimes committed on the territory of States that have ratified the treaty. The ICC is designed to complement existing national judicial systems, however, the Court can exercise its jurisdiction if national courts are unwilling or unable to investigate or prosecute such crimes. Therefore, the Court also serves as a catalyst to States' investigating and prosecuting such crimes committed either within their territories or by their nationals. The ICC's jurisdiction is not retroactive, but its very existence serves as a deterrent to future architects of genocide, war crimes and crimes against humanity by sending a strong signal that never again will such acts be met with impunity.

The legal framework of the Court was established at a United Nations-sponsored conference in Rome involving representatives of 160 countries. Following five weeks of the intense deliberations, the Rome Statute of the International Criminal Court was adopted by an overwhelming majority on 17 July 1998 [2]. By the established deadline of 31 December 2000, 139 countries had signed the Rome Statute. In a record four years, the ICC treaty was ratified by the required 60 States on 11 April 2002, and the treaty entered into force and became law on 1 July 2002.

Matters can be referred to the Court by a State Party to the Rome Statute, by the Prosecutor, and by the UN Security Council. The Court may then exercise its jurisdiction over the matter if either the State in whose territory the crime was committed, or the State of the nationality of the accused, is a party to the Statute. Non- States Parties may accept the Court's jurisdiction on an ad hoc basis. When a matter is referred by the Security Council, the Court will have jurisdiction regardless of whether the State concerned is a party to the ICC treaty. Citizens of any country fall within the jurisdiction of the Court under one of the following conditions: 1) the country where the alleged crimes occurred is a State Party to the ICC treaty; 2) that country accepted the ICC's jurisdiction on an ad hoc basis; or 3) the UN Security Council referred the situation to the Court. However, under the principle of complementarity, the Court will act only if the national court of the accused does not initiate investigations and prosecution, if appropriate. The fact that a crime has been committed by a person on the orders of a superior will not normally relieve that person of criminal responsibility. A military commander may be held criminally responsible for crimes committed by forces under his/ her command and control. Criminal responsibility may also arise when a military commander knew or should have known that the forces were committing or were about to commit such crimes, but nevertheless failed to prevent or repress their commission.

In addition, civilians effectively acting as military commanders may be held criminally responsible when they knew of or consciously disregarded information clearly indicating that crimes were being or were about to be committed.

Does the ICC violate international law by having jurisdiction over members of national forces or of peacekeeping missions? Under existing international law, the State in whose territory genocide, war crimes or crimes against humanity have allegedly been committed, or whose nationals are victims of such crimes, has the right to and is often legally obligated to investigate and prosecute persons accused of committing such crimes. The ICC Statute does not violate any principle of treaty law and has not created any entitlements or legal obligations not already existing under international law. The cooperation of a non-State Party is purely voluntary and no legal obligation is imposed on a non-State Party. The International Criminal Court will complement, not supersede, the jurisdiction of national courts. National courts will continue to have priority in investigating and prosecuting crimes within their jurisdiction. Under the principle of complementarity, the ICC will act only when national courts are unable or unwilling to exercise jurisdiction. If a national court is willing and able to exercise its jurisdiction, the ICC cannot intervene and no nationals of that State can be brought before it. The grounds for admitting a case to the Court are specified in the Statute and the circumstances that govern inability and unwillingness are carefully defined so as to avoid arbitrary decisions. In addition,

${ }^{4} \mathrm{Ibid}$ 
the accused and interested States, whether they are parties to the Statute or not, may challenge the jurisdiction of the Court or admissibility of the case. They also have a right to appeal any related decision.

\section{The Role of the UN Security Council on ICC}

The work of the Security Council and the International Criminal Court will continue to complement each other. The Rome Statute recognizes the role of the Security Council in the maintenance of international peace and security. Specifically, the treaty notes that under Chapter VII of the UN Charter, the Security Council may refer a "situation" to the Court when one or more of the crimes covered by the Statute appear to have been committed. This would provide a basis for the Prosecutor to initiate an investigation.

Since the referral of a situation by the Security Council is based on its competence under Chapter VII, which is binding and legally enforceable in all States, the exercise of the ICC's jurisdiction becomes part of the Council's enforcement measures. Its jurisdiction becomes binding even when neither the State in whose territory crimes have been committed nor the State of nationality of the accused is a party to the Statute. In those instances, the International Criminal Court, through investigation and prosecution, helps the Security Council in maintaining peace and security. This jurisdiction, resulting from a Security Council referral, enhances the role of the ICC in enforcing international criminal law. At the same time, the Court's jurisdiction is expanded to cover even nonStates Parties, in these instances.

Furthermore, the Security Council, by adoption of a resolution under Chapter VII of the UN Charter, may request that the ICC defer an investigation or prosecution for a renewable period of 12 months. This deferral is to ensure that the Security Council's peace-making efforts will not be hindered by the Court's investigations or prosecutions.

In order to ensure the independence of the Court, a Security Council referral is only one of three ways the ICC can obtain jurisdiction: a matter can also be initiated by a State Party to the treaty or by an independent Prosecutor.

\section{States Vote against the Statute}

Seven States voted against the Statute in an unrecorded vote. Three States - China, USA and Israel stated their reasons for voting against the treaty. China indicated its view that the power given to the Pre-Trial Chamber to check the Prosecutor's initiative was not sufficient and that the adoption of the Statute should have been by consensus, not by a vote. The principal objection of the United States was over the application of the Court's jurisdiction to non-States Parties. The US also stated that the Statute must recognize the role of the Security Council in determining an act of aggression. Israel stated that it failed to comprehend why the act of transferring populations into an occupied territory was included in the list of war crimes.

\section{ICC Prosecution of others Crimes}

Although there was also considerable interest in including terrorism and drug crimes in the ICC's mandate, countries could not agree in Rome on a definition of terrorism and some countries felt investigation of drug offences would be beyond the Court's resources. A consensus resolution was passed recommending that States Parties consider inclusion of such crimes at a future review conference. Treaty law in this area contains some examples of an obligation to prosecute, for example in the 1984 Convention against Torture (which contains an application of aut dedere, aut judicare in Article 5, paragraph 2. However, human rights treaties are by no means always that explicit. The 1966 International Covenant on Civil and Political Rights (ICCPR), for instance, is silent on the question whether a duty to prosecute applies to violations of the Covenant. Leaving aside the controversial question of the extent to which the Covenant applies to relations between non-state actors, Article 2, paragraph 1, requires each State party "to ensure to all individuals (...) the rights" recognized in the Covenant. Some authors have interpreted this provision as to entail a duty to prosecute, thereby invoking certain hints in this direction enshrined in statements of the Human Rights Committee. However, as the latter does not have any authority to issue binding interpretations of the ICCPR, it remains unclear, leaving aside other aspects of enforcement of the Covenant, whether a "hard" international legal duty to prosecute the Covenant's violations applies. While there is no expressed general obligation in the Rome Statute requiring non-States Parties to cooperate, all States - whether parties to the ICC treaty or not - are obliged under existing international law to bring to justice those responsible for genocide, crimes against humanity and war crimes. If States are incapable of this, they are expected to extradite suspected individuals to a state willing and able to conduct a fair trial. Moreover, in December 1973, the UN General Assembly adopted the Principles of international co-operation in the detection, arrest, extradition and punishment of persons guilty of war crimes and crimes against humanity in Resolution 3074, which declares that all States are to cooperate with each other on a bilateral or multilateral basis to bring to justice persons responsible for these crimes.

The ICC complements existing national judicial systems and while it will step in only if national courts are unwilling or unable to investigate or prosecute such crimes, the Court may invite national courts to cooperate under an ad hoc agreement. If a State chooses to conclude such an agreement, it would be bound to comply with requests for assistance. Additionally, if the Security Council refers a situation to the ICC that threatens international peace and security, it can use the powers under Chapter VII of the UN Charter to compel non- States Parties to cooperate with the ICC's requests for assistance. Mention can be made of both Antonio Cassesse's and M. Cherif Bassiouni's doctrinal opinions. In Cassese's view, before being in a position to qualify a given 
crime as an international law crime, one should ask what values are to be protected by a given legal rule and whether those values are considered important by the whole international community ${ }^{5}$ [3]. Obviously, once one starts speaking about fundamental values, one comes close to the notion of jus cogens in international law ${ }^{6}$. However, through the taking into account of values as a necessary but insufficient pre- condition of an international law crime, one implicitly and a priori limits the kinds of crimes that possibly qualify as international law crimes. For example, consistent with this theory, Cassesse argues that the crime of piracy - one of the most cited and centuries old examples of an international law crime - cannot be considered as a crime of an international legal nature as the prohibition of piracy would not protect a real, fundamental value of the international community, even though it is undeniable that it is a specific value that States have an interest in that it be protected.

The legal basis for considering an offence as crime under international law is when existing treaties and customs consider the act as an international crime, and Bantekas believes that no international offence emanates independently from general principles of international law or the criminal law of nations ${ }^{7}[4]$. Bassiouni considers a contrary view different from Bantekas that an international offence can emanate independently and lists its criteria, this debate alone contributes to the view that international criminal justice exists $^{8}$ [5]. It has the following features: first, it is a new limb of international law with evolving international procedural rules and also a rudimentary branch of law. Second, it has strong links with human rights, humanitarian law and national criminal law, which as a result has devolved gradually from state criminal responsibility to individual criminal liability ${ }^{9}$ [6]. It also has a relationship with public international law in the sense that it regulates individual conduct with the aim of protecting society, while public international law regulates the behaviour of states and this conflict is resolved on the fact that international criminal law relies to a large extent on custom, one of the sources of international law ${ }^{10}$. International crimes generally are breaches of international rules entailing the personal criminal liability of the individuals concerned ${ }^{11}$.

There are different meanings and understandings of 'international criminal law' contents as there is no single right answer as to what is incorporated in 'international criminal law' because it means different things to different people. Bassiouni for example took a broad approach of the concept when he said it includes any crime that fulfils one of ten criteria with right to extradite encompassed in a treaty, which no convention on international criminal law embodies all ten of these criteria ${ }^{12}$ [4]. This essay will take a narrower path rather than a broader approach, because International criminal law imposes criminal 'responsibility directly upon individuals, without the necessary interposition of national legal systems' as established by the Nuremburg International Military Tribunal in its decision that 'crimes against international law are committed by men, not abstract entities, and only by punishing individuals who commit such crimes can the provisions of international law be enforced ... individuals have international duties which transcend the national obligations of obedience imposed by the individual state'13. Debates now are more 'fruitfully centre on the contours of individual liability under international law, rather than its existence'14 [7].

\section{Objectives of the International Criminal Law}

The first objective or aim of international criminal law asserted by ICTY is that of the theory of retribution. This theory of punishment is associated with a famous jurist Immanuel Kant. According to him and his disciples in this theory, it is necessary to punish criminals, because of the fact that it will bring future benefits for the society. But it was held by ICTY in Aleksovski case, that the objective to inflict punishment is not the revenge from the criminal, rather the primary purpose is expressing outrage at the crimes. Moreover in Todorovic' Case, the principle has been laid down by ICTY that a fair and balanced approach should be adopted regarding the punishment, which clearly shows that it should be proportional according to the nature of crimes ${ }^{15}$ [8]. The second main objective asserted by ICTY is of deterrence. Jeremy Bentham is the founder of this theory of punishment and he and other jurists have based this theory on utilitarian approach, and they call it the best justification of punishing a criminal, which also speaks about the future benefits of the punishment, that through the implementation of this theory and deterrence other criminals will be prevented from commission of crimes, and on the other hand, rest of the population and ordinary citizens will be protected from these criminals ${ }^{16}$. But certain other jurists have severally criticized this theory of punishment. They are of the view

\footnotetext{
${ }^{5}$ Antonio Cassese, International Criminal Law (2nd edition, Oxford: Oxford University Press, 2003), 23-25

${ }^{6}$ J. Wouters and S. Verhoeven, "The Prohibition of Genocide as a Norm of Ius Cogens and Its Implications for the Enforcement of the Law of Genocide", Institute for International Law, Working Paper No 69, www.internationallaw.be, forthcoming in International Criminal Law Review (2005/3).

${ }^{7}$ Bantekas IIias and Nash Susan, 'International Criminal Law' (3rd edition, New York, Routledge-Cavendish,2007) p 6

${ }^{8}$ Bassiouni M. Cherif(ed),'International Criminal Law'(New York, Transnational,1986) p 277

${ }_{9}^{9}$ Antonio Cassese, International Criminal Law (2nd edition, Oxford: Oxford University Press, 2008), p 9

${ }^{10}$ Ibid p 10

${ }^{11}$ Ibid p 11

${ }^{12}$ Bantekas Ilias and Nash Susan, op.cit n1 p7

${ }^{13}$ 'Nuremberg IMT: Judgment and Sentence' (1947) 41 AJIL 172, 221

${ }^{14}$ Robert Cryer, 'Prosecuting International Crimes: Selectivity and the International Criminal Law Regime'(Cambridge, Cambridge University Press,2005) p2

${ }^{15}$ Robert Cryer, Hakan Friman, Darryl Robinson, Elizabeth Willmshurts, An Introduction to International Criminal Law and Procedure,23-25

${ }^{16}$ ibid
} 
that no limits have been prescribed for this type of punishment, hence being unlimited in nature it may not be justified because of inflicting unnecessary punishment at several places. Moreover by creating deterrence innocent people may also be prosecuted and punished in consequence15. Besides these two main theories of punishment, sometimes some other objectives are also referred as objectives of international criminal law. At one place after examining the trials of Yugoslavia, Rwanda, and Uganda, Golash, the author has finally concluded that punishment is not a sufficient deterrent for preventing the international crimes ${ }^{17}[10]$. According to a newly emerged 18th century concept, the basic aim of international criminal law is the reformation of the offender. Modern human rights activists widely support this notion and say that a criminal may be reformed, and if such is the case then the primary purpose of punishment should be to reform a criminal accordingly. This was practiced in Erdemovic case, which being a young Bosnian Croat, and founded involved in Bosnian massacre, was sentenced to a short term of five years imprisonment, due to his young age and capability of reformation ${ }^{18}$.

\section{Existence of International Criminal Justice and Liability}

The focus of this essay on individual criminal liability under international law will mean exclusion of two other known rules under 'international criminal law', that is, the concept of international crime of state ${ }^{19}$, though controversial and originally included in Article 19 ILC Draft Articles on State Responsibility ${ }^{20}$ [10,11-12]. It was later dropped in the 2001 final Articles sent to the General Assembly ${ }^{21}[13]$. State criminal liability still remains controversial and that is the reason why this essay placed it outside its scope. The other excluded part are treaties like the Vienna Convention Against the IIIicit Trafficking in Narcotic Drugs and Psychotropic Substances-1998 only place duty on state to make it criminal conduct municipally ${ }^{22}$, without individual criminal responsibility under international law [14]. International law cannot on itself criminalize such conduct and therefore is better placed outside the scope of this essay.

Treaty crimes are controversial and not universally accepted ${ }^{23}$. Similarly Cassese argued in favour of the controversy surrounding torture under international law $^{24}$ while Bruno and Andreas disagreed and argued against this ${ }^{25}[3,15]$. Even though crimes like torture and terrorism entailing individual liabilities are still controversial in international law, these acts can still be said to be sufficient to rise to the level of concerns of the international community as serious crimes but the same can not be said of treaty crime like interference with a submarine cable ${ }^{26}$. Apart, treaty crimes were disqualified from ICC jurisdictions and therefore 'excluded from the regime of International Criminal law enforcement ${ }^{27}$. Piracy has become obsolete, it does not properly meet the requirement of International Crime ${ }^{28}$, thus, it will not be discussed in this essay. One might be tempted to argue that there is no such thing as 'international criminal justice', due to the several exclusion canvassed in this essay especially the weakness of international criminal law in piracy, torture, drug trafficking, money laundering, cyber crime, bribery and corruption; but contrary to this view, these exclusions leave the accepted four categories of 'crime accepted in the latter half of twentieth century as the core international crimes which international law itself criminalizes' ${ }^{29}$. The principle of pacta sunt servanda, (agreement must be respected) align with treaty crime, what the parties to the treaty called crime can only be criminalize, if they decide that drug trafficking and corruption would be too expensive to prosecute and therefore excluded it from the treaty crime, it will takes another treaty to criminalize such crime. Corruption for instance has become incidental to other serious crimes like genocide and terrorism, the proceeds of corruption in Africa for instance are being used to purchase weapons of wars for terrorism and genocide. Corruption should therefore receive attention being given to genocide under international criminal law. The principle of 'tracing' to every financial institution could be applied by prosecutors and investigators to trace proceeds of corruption that may likely be used to procure weapons for genocide and terrorism. If such is found by the investigator that the proceed of corruption is also a 'financial weapon of mass destruction', such proceed must be forfeited to the international criminal court. We must look at corruption as the new wave for genocide, terrorism and crime against humanity.

\footnotetext{
${ }^{17}$ Ed. Larray May, Vanderbilt University and Centre for Applied Philosophy and Public Ethics, 'International Criminal Law and Philosophy", (Cambridge, New York, Melbourne, Madrid, Cape Town, Singapore, São Paulo, Delhi, Dubai, Tokyo: Cambridge University Press, 2010 ), 10.

${ }^{18}$ Robert Cryer, Hakan Friman, Darryl Robinson, Elizabeth Willmshurts, 'An Introduction to International Criminal Law and Procedure', $28-29$.

${ }^{19}$ Shabtai Rosenne, 'State Responsibility and International Crimes: Further Reflections on Article 19 of the Draft Articles on State Responsibility'(1997--1998) 30 NYUJIL p145

${ }^{20}$ Report of the International Law Commission on the Work of its Forty-Eighth Session UN GAOR 51st Sess. Supp. No. 10, p 131

${ }^{21}$ Crawford James, 'The International Law Commissions' Articles on State Responsibility: Introduction, Text and Commentaries' (Cambridge, Cambridge University Press, 2002), p16.

${ }^{22}$ Robert Cryer, op.cit , n 5 ,p 3

${ }^{23}$ Article 1, Vienna Convention Against the Illicit Traffic in Narcotic Drugs and Other Psychotropic Substances, 1988

${ }^{24}$ Antonio Cassese, International Criminal Law (Oxford: Oxford University Press, 2003), pp 117-19

${ }^{25}$ Bruno Simma and Andreas Paulus, 'The Responsibility of Individuals for Human Rights Abuses in Internal Conflicts: A Positivist View' (1999) 93 AJIL $302,313$.

${ }^{26}$ Contrary to the 1982 United Nations Convention on the Law of the Sea, 516 UNTS 205, Article 113

${ }^{27}$ Robert Cryer, op.cit , n 5 ,p 3

${ }^{28}$ Antonio Cassese, op.cit n 3 , p 4

${ }^{29}$ Ibid p 4
} 
The criminal-law system in underdeveloped communities is specially noted for laying stress on the external act that constitutes the actus reus of a crime while almost entirely disregarding the subjective element of fault as a condition of criminal liability. Punishment is founded on the principle based on vengeance for the damages or harm suffered by the victim of a wrongful act. It is a salient principle of legal ethics that a person ought not to be punished for wrongful acts unless the perpetrator's conduct was attended by a blameworthy state of mind (fault). The principle encapsulated in the maxim actus non facit reum, nisi mens sit rea (an act does not render the perpetrator culpable unless there is a criminal intention) thus represents a moral directive of the legal idea. Although almost all the developed legal systems of the world recognize instances of absolute or strict liability, those instances would, in ethically-based criminal justice systems, remain restricted to highly exceptional instances of technical misdemeanors or where possession of or control over objects that are inherently dangerous or likely to be used for criminal purposes would merit invoking the notion of risk liability.

The four areas to be discussed are Genocide, Crimes against humanity, War Crimes and the Crime of Aggression. In further support of this, these remaining areas of discussion have been the only crimes for which International Criminal Tribunals (ICTs) have punished offenders. The essence of justice is to satisfy the three ways passage, justice for the accused, victim and the community. Apart from this, these four crimes are expressly stated in the Rome Statutes of $1998^{30}$ [1]. They are also streamlined in the ILC Draft Code of Crimes against the Peace and Security of Mankind ${ }^{31}$. Article 1 of the Draft Code sates that 'Crimes against the peace and security of mankind are crimes under international law and punishable as such, whether or not they are punishable under national law' [16]. These suggest on the other hand that 'international criminal justice' subsist. The problem international law encounters in dealing with individuals is complicated by the view that the individual is merely an object and not a subject of the law of nations. It can be argued that the individual has received significant protection of his human rights within the system of international law. Since the 1948 declaration of Human Rights, an individual owes concrete duties to the international society under international law [17]. One of these is to refrain from committing crimes with an 'international element'. A crime generally consists of two elements; mens rea (mental element) and actus reus (physical conduct). International criminal law as a branch of international law derives its source from its primary sources such as treaties, customary law and secondary sources such as Security Council resolutions and international tribunals established by Security Council Resolutions, general principles of International Criminal Law and subsidiary sources such as general principles of law recognized by the community of states ${ }^{32}$ [3]. The threefold objectives of International Criminal Law will reflect in this essay while discussing the four core areas of international crime. The threefold objective is; to prevent, prosecute and punish offenders and consequently make the process beneficial to all people ${ }^{33}$ [4]. If international criminal justice can not serve this purpose then it has failed and it will be better considered moribund. These are present in the four core areas of International Criminal Law to be discussed.

\section{The Core of International Criminal Law}

GENOCIDE: Genocide is an accumulation of casualties offences targeted at a group or the substantial part of a group by the offender(s).ICJ affirmed the dual responsibilities of State responsibility and individual criminal liability in the Genocide Convention of 1948 in the Bosnia V Serbia Case ${ }^{34}$ when it construed Article I of the Convention as imposing the duty to punish and prevent genocide as well as conferring an obligation on states to refrain from act of genocide [18]. Apparently, this broadened the Article to impose responsibility on state to punish genocide in line with international criminal justice objectives. Prohibition of Genocide as a matter of jus cogen was also confirmed by the ICJ in the Barcelonia Traction Case ${ }^{35}$ while referring to erga omnes obligations of the 1948 Genocide Convention on states whose nationals are not even victims of genocide ${ }^{36}[19,4]$. This decision on prohibition of genocide as jus cogen and its erga omnes obligations fulfill one of the threshold objectives of International criminal justice, that is, crime prevention. Articles II and III of the 1948 Genocide Convention defines genocide as 'any of the following acts committed with intent to destroy, in whole or in part, a national, ethnical, racial or religious group' [20]. This definition was a replica of Articles 2 and 4 of ICTR and ICTY statutes respectively with listing of punishable acts under the Articles. Genocide is not limited to the four groups in the definitions but depends on the element, which is mens rea of the perpetrators, whose intention must be to destroy a whole or in part a particular group designated under the terms of the convention' while actus reus requires the perpetration of the act of destroying a group in part or whole ${ }^{37}$. Mens rea as an element will be linked in all the core crimes as an important element for conviction as indicated under Article 30 of the 1998 Rome Statute establishing the ICC [1]. In ICTY Prosecutor V Krstic ${ }^{38}$,

\footnotetext{
${ }^{30}$ Article 5 Rome Statute, 1998

${ }^{31}$ Draft Code of Crimes Against the Peace and Security of Mankind, in Report of The International Law Commission on the Work of its Forty-Eighth Session, UN Doc.A/51/10, Articles 16-20

${ }^{32}$ Antonio Cassese, op.cit n 3, p 27

${ }^{33}$ Bantekas Ilias and Nash Susan,op.cit n1 p 12

${ }^{34}$ ICJ Reports 2007

${ }^{35}$ ICJ Reports 1970, 3

${ }^{36}$ Bantekas IIias and Nash Susan, op.cit n1 p139

${ }^{37}$ Ibid p 141

${ }^{38}$ ICTY Judgement 2001,paragraph 582-84
} 
Journal of Forensic Science \& Criminology

General Krstic was convicted of genocide by the ICTY Trial chamber on consideration of the elements for his involvement in the 1995 massacre of Bosnia Muslim males in the Srebrenica area [21].

The prosecutor must prove intent to destroy a particular group within a geographical location and a substantial part of the group; also the act and the conduct must be linked with the accused. The prosecutor was able to prove his case in fulfillment of threshold objectives of international criminal justice that was achieved in the prosecution and punishment of General Krstic for genocide. General Krstic had opportunity to prove his case. He argued in the process that Bosnia Muslim males in Srebrenica did not form a substantial part of the general Muslim population in Bosnia, an argument that was rejected by the ICTY Appeals Chamber. Despite several merits of the Convention, it has ineffective enforcement mechanisms, for example Article IV of the Convention demands trial within the jurisdiction of the State where genocide occurred. This is a flaw in the sense that national prosecutors are always reluctant to bring action against the perpetrator of the crime. Article VIII conferred power on the UN under the charter to take action referred by contracting parties regarding genocide, while Article IX gave the ICJ jurisdiction over states disputes regarding interpretation, application and fulfillment of the convention. The flaw in the enforcement is obvious in the sense that the UN General Assembly only once by resolution 37/123D(1982) pronounced without legal reason the mass killing of Palestinians by Christian Falangist troops as genocide act and subsequently, the Bosnia $\boldsymbol{V}$ Serbia case was brought before the ICJ on genocide for the first time in $1993^{39}$ [18,6]. One might again say that 'International Criminal Justice' does not exist due to the failure in the enforcement mechanism but having argued the existence of elements of crime in genocide above and the threefold objectives of international criminal justice, that is to punish, to prevent and prosecute; one can convincingly say that 'International Criminal Justice' exists. On the other hand, all these features cannot be found in piracy and treaty crime like drug trafficking. Another core area of international criminal law is War Crimes.

WAR CRIMES: The first instance of international trial of a war crime took place in Breisach, Germany in 1474, when twenty seven judges of the Holy Roman Empire sat in judgment of Peter Van Hagenback for violating the 'law of God and man' by allowing his troop to rape, murder, and pillage. He was convicted, sentenced to death, and executed ${ }^{40}[22]$. This judgment alone reflects the threefold principles of International Criminal Justice. The laws of war of antique origin rest on two principle of necessity and the principle of humanity. Under the former, that which is necessary militarily to vanquish the enemy may be done. Under the latter, that which causes unnecessary suffering is forbidden ${ }^{41}$. This second principle has been elaborated in our era as jus in bello with its basis in international humanitarian law .Cassese categorized war crimes as crime committed against person not taking part or no longer taking part in hostilities, crime committed as a result of use of prohibited means of warfare or resorting to method of warfare against combatants or civilians, crime committed by use of children under the age of fifteen to participate in hostilities, crime against specially protected persons and crime consisting of improper use of emblem and signs ${ }^{42}[3,6]$. Geneva Conventions of 1949 added new categories of war crimes and termed it 'grave breaches of Geneva Conventions' which are an extension of 'substantive law and the law for the enforcement of substantive prohibitions ${ }^{\prime 43}$ and two additional protocols of 1977 added other rules about war fighting [2].

War crime originally embrace inter state conflicts and not intra state conflicts but both now amount to war crimes and for a crime to be a war crime it must be linked to international and internal conflicts. The ICTY Appeal Chamber held in ICTY Prosecutor $V$ Tadic $^{44}$ that armed conflict exists where there is 'resort to armed force between States or protracted armed violence between governmental authorities and organized groups or between such groups within a State' [23]. It is no longer necessary to categorize war crimes by distinguishing international armed conflict from internal armed conflict due to the decision of this case ${ }^{45}$. Article 2 of the ICTY Statutes provides for criminal jurisdiction over grave breaches of the Geneva Conventions while Article 3 covers international armed conflicts, war crime apart from grave breaches and non international armed conflicts. The objective element can be inferred from 'substantive rule of international humanitarian law allegedly violated' ${ }^{46}$ while the subjective elements or mens rea are enumerated in the 'grave breaches' of the convention like 'willful killing' (of prisoners of war), torture including biological experiments, 'willfully' causing great suffering ${ }^{47}$. The word 'willful' denotes criminal intent to commit a prohibited act of war crimes. The punishment of a war crime will be prosecuted by a soldier's own state if it is a small scale war crime, but if it is a major war crime then it will fall to the ICC trial by virtue of Article 8 of ICC Statutes ${ }^{48}$ and Article 5 that gave it jurisdiction over 'the most serious crimes of concern to the international community as a whole' [24]. All these reflect the threefold Principle of international

\footnotetext{
${ }^{39}$ Antonio Cassese, op.cit n 3, p131

${ }^{40}$ Aryeh Neier, 'War Crimes' (1st edition, New York, Randorm House Inc,1998) p 12

${ }^{41}$ Ibid

${ }^{42}$ Antonio Cassese, op.cit n 3 ,p p 88-89

${ }^{43}$ Ibid p 31

${ }^{44}$ ICTY judgement, 1995 paragraph 70

${ }^{45}$ Ibid paragraph 57

${ }^{46}$ Antonio Cassese, op.cit n 3 p 87

${ }^{47}$ Ibid p 92

${ }^{48}$ May Larry(ed), 'War Essays in Political Philosophy' (Cambridge, Cambridge University Press,2008) p 274
} 
criminal justice since war crime set up conventions, Protocols and Statutes to prevent war crime and prosecute or punish offenders by tribunals and other courts, when such breaches occur in respect of the presence of international elements of crime stated earlier.

\section{Crime against Humanity}

This concept can be traced in its first expression to Article 6(c) of the charter of Nuremberg Tribunal in 1945 which states that: crime against humanity: namely, murder, extermination, enslavement, deportation and other inhuman acts committed against any civilian population, before or during the war, or persecutions on political, racial or religious grounds in execution of, or in connection with, any other crime within the jurisdiction of the Tribunal, whether or not in violation of the domestic law of the country where perpetrated [25].

It is an international customary crime affirmed by the last sentence that it shall be made applicable whether or not it violated national law of the country where the crime was committed. There was no other definition of a crime against humanity until 1993 when Article 5 of the ICTY Statutes reaffirmed the Nuremburg charter. Meanwhile, the prosecution of the crime at the national level with domestic statutes took place with influence of Nuremburg charter; the punishment of the crime even though at national level limits the 'omnipotence of state' with the charter of Nuremburg. The crime is prohibited whether or not it is perpetrated in time of peace or war. The element of the crime as at 1945 is 'contextual presence' of armed conflict but now the element has changed to 'widespread or systemic attack on the population'49. The subjective element is intent to commit the listed acts, that is, intent to commit murder or intent to inflict serious injury and where an accused is acting as an agent, his reasonable awareness of his risk of his action and its consequences on his victims make it sufficient subjective element ${ }^{50}$. Any individual act against one or two of the listed crimes in the definition constitutes act of crime against humanity. The IMT had applied new law when it found some defendants guilty of crime against humanity in conjunction with other crimes ${ }^{51}$. The presence of threefold principles of international criminal justice makes its existence a crime under International Criminal Law. The elements, prevention, prosecution and punishment of the act of crime against humanity by IMT and frequent reference to its charter by national courts are enough proof of this.

\section{Crime of Aggression}

Article 6(a) of the London Charter of the International Military Tribunal(IMT) 1945 did not separate crimes against peace from aggressive war while the 1954 draft code of the International Law Commission expanded the definition when it defined it as 'as an offence against the peace and security of mankind'. The UN General Assembly in 1974 adopted a resolution containing a definition of aggression in a generic way. Article 5 (2) of the definition differentiates between aggression which gives rise to international responsibility and a war of aggression which is a crime against international peace. The definition agrees that not every act of aggression constitutes a crime against peace but only a war of aggression does ${ }^{52}$ [26]. The definition in its acceptance especially of Article 3(g) was up held by the ICJ in the Nicaragua case $^{53}$ to mirror Customary International Law [27]. Article 2(4) of the charter of UN prohibits the use of force in war or short of war except in self-defense in Article 51 of the charter and collective security in Article 39 and 42 of the charter. The UN Security Council under Chapter VII has discretion to determine what constitutes 'breach of the international peace or aggression'. Article 6(a) of IMT states that crime against peace includes the 'planning, preparation, initiation or waging' war of aggression. A person charged with crimes against peace may also be guilty of planning, preparation, initiation and waging war of aggression. Initiation is linked to the commencement of the war, while waging continues as long as the war is not terminated. In the Nuremberg trial, conspiracy, planning and preparation to wage war were scrutinized. Perpetrators may be brought to trial and punishment even if no war materializes ${ }^{54}$ [26]. It was held in USA v Von Leeb (High Command Case) ${ }^{55}$ that the criminality of aggressive war attaches only to 'individuals at the policy- making level' and this was affirmed by another tribunal in the same year in the IG Farben case $^{56}[28,29]$.

The definition of Aggression by the UN General Assembly is within actus reus but the mens rea of aggression was laid to rest in the High Command Case ${ }^{57}$ stating that almost all state prepare for war and 'as long as there is no aggressive intent, there is no evil inherent in a nation making itself militarily strong. Thus, aggressive intent is the mens rea of an act of aggressive war. There is international element and threefold principle of International Criminal Justice as seen in the discussion here and therefore the crime can be punished under international customary law and the UN Security Council power under Chapter VII prevents

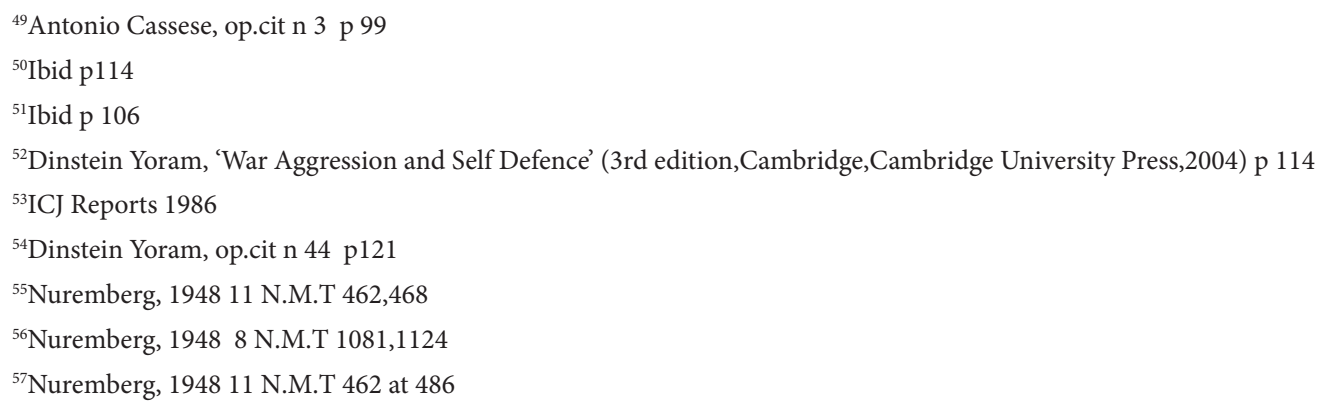


the crime. Importantly, the House of Lords in $\boldsymbol{R} V$ Jones held in 2006 that the perpetrator may not be punished and prosecuted because it is criminalized under customary international law and by Article 5(2) of the Rome Statutes, it is subject to international court jurisdiction due to lack of clarity in its definition. In essence, if there is no International Criminal Justice, the perpetrators of this crime would have escaped justice due to inability of national courts to prosecute and punish the offence. This court decision again buttresses the importance of international criminal justice the existence of which cannot be denied despite its weaknesses. Consequently, in the 2005, UN World Summit, States resolved to protect civilian populations from the four cores of international criminal law not only in their own jurisdiction but by helping one another to afford such protection, including investigation and prosecution when such crimes have been committed ${ }^{58}[30]$.

\section{Institutional Roles in International Criminal Justice}

Articles 8 and 9 of the ICTR and ICTY statutes respectively gave concurrent jurisdiction to the tribunals, with national courts being able to prosecute for violations of serious IHL [31]. Paragraph 2 gave the tribunal primacy over national courts especially when they appear unreliable ${ }^{59}$ ICTY, ICTR, ICC and Special Court for Sierra Leone, provided the foundations of the international criminal law regime which became more solid in the 1990s. International Tribunals may try again somebody who had been tried by a national court, if the trial is unfair and ineffective. These tribunals have been successful in prosecution and punishment of international crimes. This strengthens the threefold principle of international criminal justice and the proof of its effectiveness; this however is in contrast to the ICC which only acts as a complementary or subsidiary to national courts ${ }^{60}$. This on the other hand may give an impression of non existence of International Criminal Justice. The justification for this are based on unwillingness to flood the ICC with cases and respect for state sovereignty which is not strong enough considering the extent of international crimes.

The court can only try cases based on national courts' inability and unwillingness to try the offence. This still incapacitates the ICC. This made perpetrators of the four cores of international crimes go unpunished, because in most cases, they are shielded by same state that tried them. The ICC is supposed to block the immunity from punishment of the crimes; however national court can not try individuals already tried by ICC under the statutes in respect of the four core crimes ${ }^{61}$ [32]. The gradual development of the ICC to attain the stage of punishment, prevention and prosecution of the international crimes; since formation of ICC statutes from the drafting conference at Rome in 1998; has come under US objection and refusal to ratify its treaty, even when many countries had ratified it. The US believes that ICC can render false justice and become a forum for launching 'politically motivated attack' on the US ${ }^{62}[33,34]$. Also, the Security Council can order the ICC under Chapter VII of UN charter to suspend prosecution; and most times it is prohibited from prosecuting matters before the Security Council under Article 39 and 42 of the charter ${ }^{63}$. The ICC is not a perfect model of symmetrical enforcement; its statute preserves pockets of immunity and elements of asymmetrical enforcement, coupled ${ }^{64}$ with the Security Council's power to suspend trial. This may bring to the fore the argument that there is no international criminal justice, however the success of ICTY, ICTR and even national court prosecutions and punishment of international crimes raised hope of existence of international criminal justice. ICC treaty ratifications so far and proposed amendment to Rome Statutes on $11^{\text {th }}$ June 2010 in Kampala Uganda where international criminal justice will advance to fight impunity ${ }^{65}$ shows that the court will soon overcome its problems [35,36].

\section{Conclusion}

The Rome Statute of the ICC created a truly international criminal justice system as it reflects input from all major legal systems and traditions. The Statute recognizes a full range of rights of the accused, and even extends the standards embodied in major international human rights instruments. It will provide impartial and qualified judges, due process and fair trials to individuals accused of crimes falling within the jurisdiction of the Court. Additional protections of the rights of the accused include the screening mechanisms by the investigative and prosecutorial organ and the judicial organ of the Court, which are designed to protect innocent individuals from frivolous, vexatious or politically motivated criminal investigations or prosecutions. In addition, the persons who are entrusted with making decisions relating to the initiation of a criminal investigation or trial must possess the highest qualifications of competence, independence and impartiality.

\footnotetext{
${ }^{58}$ Review conference, Resolution ICC-ASP/8/Res 6 in International Criminal Court Newsletter January 2010(www.icc-cpi.int/menus/ASP/) (accessed on 20 th May 2010)

${ }^{59}$ Antonio Cassese, op.cit n 3 p 339

${ }^{60}$ Ibid p 342

${ }^{61}$ Schabas Williams, 'An introduction to the International Criminal Court' (Cambridge,Cambridge University Press, 2001) p 68

${ }^{62}$ Mayerfeild Jamie, 'Who shall be Judge?:The United States,the International Criminal Court,and the Global Enforcement of Human Rights'(2003) 25 Human Rights Quarterly 93-129 AT 126

${ }^{63}$ Ibid p 65

${ }^{64}$ Ibid

${ }^{65}$ Review conference ,Resolution ICC-ASP/8/Res 6 in International Criminal Court Newsletter January 2010(www.icc-cpi.int/menus/ASP/) (accessed on 20 ${ }^{\text {th }}$ May 2010)
} 
Furthermore, the ICC Statute also contains elaborate provisions (over 60 articles) on criminal law principles, investigation, prosecution, trial, cooperation and judicial assistance and enforcement. These provisions required the harmonization of divergent and sometimes diametrically opposed national criminal laws and procedures. That agreement was reached on these highly technical matters represents a major achievement in international law. The ICC prosecutors and investigators are mostly from developed countries, their screenings in my opinion most often favoured developed countries than third world countries but It is rational to agree that International Criminal Justice exists, as its threefold element are active within the four cores of international criminal law, but selective punishments of offenders is the problem of International Criminal Justice. Offenders in third world nations are punished, while some in developed countries go with impunity. This seems unjustified.

\section{References}

1. Rome Statutes (1998)

2. Geneva Conventions of 1949.

3. Antonio Cassese (2003) International Criminal Law. Oxford: Oxford University Press.

4. Bantekas I, Nash S (2007) International Criminal Law. 3rd edition, New York, Routledge-Cavendish.

5. Bassiouni MC (1986) International Criminal Law. New York, Transnational.

6. Antonio Cassese (2008) International Criminal Law. 2nd edition, Oxford: Oxford University Press.

7. Robert Cryer (2005) Prosecuting International Crimes: Selectivity and the International Criminal Law Regime. Cambridge, Cambridge University Press.

8. Robert C, Hakan F, Darryl R, Elizabeth W (2014) An Introduction to International Criminal Law and Procedure. Cambridge University Press 23-25.

9. Ed. Larray May (2010) Vanderbilt University and Centre for Applied Philosophy and Public Ethics, International Criminal Law and Philosophy. Cambridge, New York, Melbourne, Madrid, Cape Town, Singapore, São Paulo, Delhi, Dubai, Tokyo: Cambridge University Press.

10. Shabtai Rosenne (1997) State Responsibility and International Crimes: Further Reflections on Article 19 of the Draft Articles on State Responsibility. NYUJIL 30 .

11. Report of the International Law Commission on the Work of its Fifty-Eighth Session UN GAOR 51st Sess. Supp

12. ILC Draft Articles on State Responsibility 2001

13. Crawford James (2002) The International Law Commissions' Articles on State Responsibility: Introduction, Text and Commentaries. Cambridge, Cambridge University Press.

14. Vienna Convention against the Illicit Trafficking in Narcotic Drugs and Psychotropic (1998).

15. Bruno S, Andreas P (1999) The Responsibility of Individuals for Human Rights Abuses in Internal Conflicts: A Positivist View. The American Journal of International Law 93: 302.

16. Draft Code of Crimes against the Peace and Security of Mankind, in Report of The International Law Commission on the Work of its Forty-Eighth Session, UN Doc.A/51/10.

17. Human Rights Declaration of 1948.

18. Bosnia V Serbia Case (2007) International Court of Justice Reports.

19. Barcelonia Traction, Light and Power Company, Limited (1970) International Court of Justice Reports.

20. Genocide Convention of 1948.

21. ICTY Prosecutor V Krstic (2001) ICTY Judgment.

22. Aryeh Neier (1998) War Crimes. 1st edition,New York, Randorm House Inc.

23. ICTY Prosecutor V Tadic (1995) ICTY Judgment.

24. May Larry (2008) War Essays in Political Philosophy. Cambridge, Cambridge University Press.

25. Charter of Nuremberg Tribunal.

26. Dinstein Yoram (2004) War Aggression and Self Defence. 3rd edition,Cambridge,Cambridge University Press.

27. Nicaragua case (1986) ICJ Reports.

28. USA v Von Leeb (High Command Case) Nuremberg, 194811 N.M.T 462,468.

29. IG Farben case Nuremberg, 19488 N.M.T 1081,1124

30. Review conference (2017) Resolution ICC-ASP/8/Res 6 in International Criminal Court Newsletter.

31. ICTY and ICTR Statutes.

32. Schabas Williams (2001) An introduction to the International Criminal Court. (Cambridge, Cambridge, University Press.

33. Mayerfeild J (2003) Who shall be Judge?: The United States, the International Criminal Court and the Global Enforcement of Human Rights. Human Rights Quarterly 25: 93.

34. Bassiouni MC (2004) Introduction to International Criminal Law (Ardsley, Transnational).

35. Broomhall B (2003) International Justice and the International Criminal Court: Between Sovereignty and the Rule of Law. Oxford: Oxford University Press.

36. United Nations (2006) Report of the International Law Commission. Fifty-eighth sessions. 


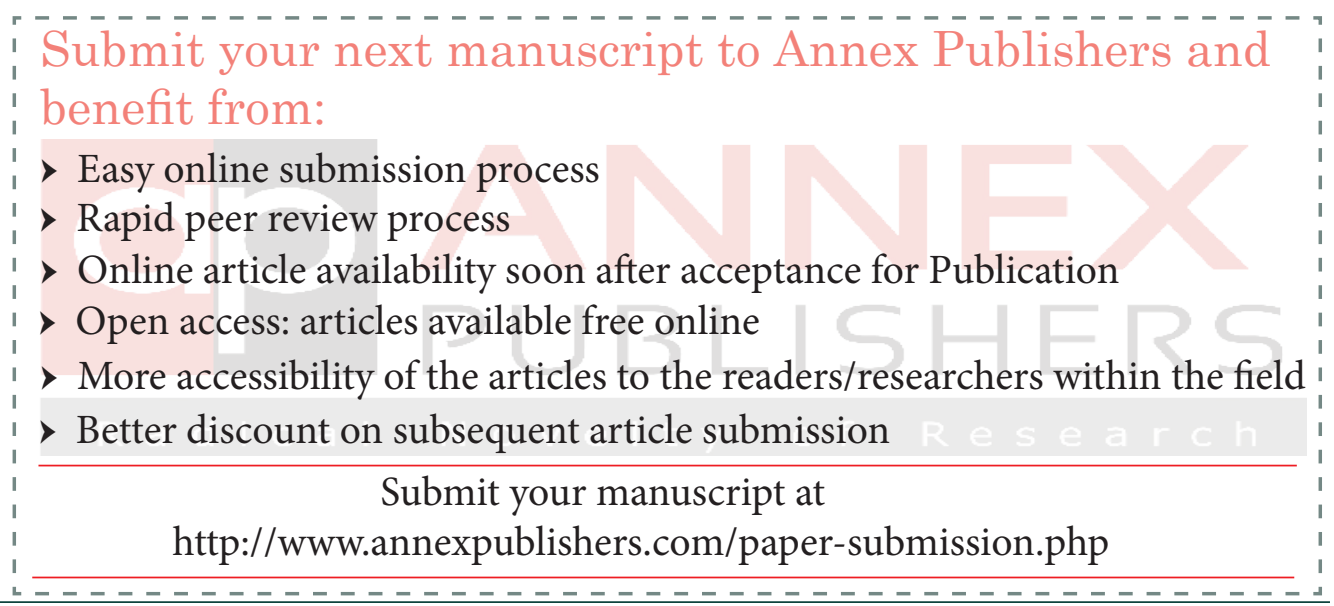

